\title{
PENGARUH MODEL PEMBELAJARAN MAKE A MATCH TERHADAP PEMAHAMAN TEKS NEGOSIASI SISWA KELAS X SMK NEGERI 1 PATUMBAK TAHUN PEMBELAJARAN 2017/2018
}

\author{
Oleh \\ Cunda Rossairy Gewa Prasasti (Cundarossairy08@gmail.com) \\ Drs. Sanggup Barus, M.Pd.
}

\begin{abstract}
ABSTRAK
Penelitian ini bertujuan untuk mengetahui pengaruh model pembelajaran make a match terhadap kemampuan memahami teks negosiasi siswa kelas X SMK Negeri 1 Patumbak Tahun Pembelajaran 2017/2018. Penelitian ini merupakan penelitian eksperimen dengan desain penelitian one group pre-test dan post-test design. Populasi penelitian ini adalah semua siswa kelas X SMK Negeri 1 Patumbak yang terdiri dari 6 kelas dengan jumlah siswa 213 orang dan diperoleh sampel sebanyak 34 orang siswa. Teknik pengambilan sampel dilakukan secara random kelas. Berdasarkan hasil penelitian diperoleh kesimpulan bahwa kemampuan memahami teks negosiasi sebelum menggunakan model pembelajaran make a match dalam kategori kurang dengan nilai rata-rata 54. Kemampuan memahami teks negosiasi setelah menggunakan model pembelajaran make a match dalam kategori baik dengan nilai rata-rata 84,9. Selanjutnya hasil uji "t" diperoleh nilai $t_{\text {hitung }}=5,45$ dan setelah dikonsultasikan dengan $t_{\text {tabel }}$ pada taraf signifikan $\mathrm{a}=0,05$ dengan $\mathrm{dk}=(\mathrm{N}+\mathrm{N}-2)=62$, karena $\mathrm{t}_{\text {hitung }}$ $>\mathrm{t}_{\text {tabel }}$ yaitu 5,45 > 2,04 maka $\mathrm{h}_{\mathrm{a}}$ diterima. Hal ini membuktikan bahwa model pembelajaran make a match berpengaruh signifikan terhadap kemampuan memahami teks negosiasi siswa kelas X SMK Negeri 1 Patumbak Tahun Pembelajaran 2017/2018.
\end{abstract}

\section{Kata Kunci: Model Pembelajaran Make a Match, Teks Negosiasi}

\section{PENDAHULUAN}

Sesuai dengan kompetensi dasar pembelajaran Bahasa Indonesia dalam kurikulum 2013, salah satunya adalah memahami struktur dan kaidah teks negosiasi, baik melalui 
lisan maupun tulisan. Jika dikaitkan dengan empat kemampuan berbahasa, memahami termasuk ke dalam kemampuan membaca. Kemampuan membaca merupakan salah satu kemampuan yang sangat penting, dengan tujuan mendapatkan informasi dari teks yang dibaca, dan lebih dari itu melalui kegiatan membaca diharapkan mampu memahami, menerapkan, dan menganalisis informasi yang dibaca dari teks, dalam pelajaran ini siswa diharapkan mampu memahami isi teks negosiasi.

Negosiasi secara umum adalah suatu bentuk interaksi sosial antara dua pihak atau lebih yang berusaha untuk menyelesaikan tujuan yang berbeda dan bertentangan demi mencari jalan keluar dan kesepakatan bersama. Ketika bernegosiasi, pihak yang terlibat harus mampu menyampaikan tujuannya dengan baik dan mampu memberikan tanggapan dengan baik juga. Jika tidak, hal tersebut dapat mengakibatkan masalah tidak dapat diselesaikan atau justru malah menimbulkan masalah baru.

Namun kenyataannya, pembelajaran memahami teks negosiasi masih rendah. Salah satu kenyataan yang menunjukkan hal itu adalah dari hasil penelitian skripsi sebelumnya yang dilakukan oleh Banjarnahor bahwa kemampuan memahami siswa masih kurang memuaskan, dengan hasil 61,68. Siswa mengalami masalah dalam memahami pelajaran karena guru masih menggunakan model pembelajaran konvensional belum menggunakan model pembelajaran yang aktif dan inovatif, sehingga siswa cepat merasa bosan pada saat mengikuti proses pembelajaran.

Data lain juga didapat dari penelitian sebelumnya yang dilakukan oleh Hirmainy yang menyatakan kemampuan siswa memahami teks negosiasi masih kurang memuaskan. Hasil penelitian beliau mengemukakan bahwa kemampuan rata-rata siswa dalam memahami teks negosiasi adalah 63,33. Nilai tersebut tergolong rendah dalam pencapaian hasil belajar.

Data selanjutnya diperoleh dari penelitian yang yang dilakukan oleh Ningsi yang menunjukkan nilai rata-rata memahami teks negosiasi siswa yaitu 68. Padahal, model pembelajaran yang digunakan oleh peneliti tersebut juga merupakan salah satu model 
pembelajaran inovatif yang menjadi salah satu model belajar unggulan untuk diterapkan. Namun hasil nilai siswa tersebut masih tergolong rendah.

Berdasarkan penelitian-penelitian tersebut jelas bahwa kemampuan memahami teks negosiasi tergolong rendah. Hasil wawancara penulis dengan guru Bahasa Indonesia SMK Negeri 1 Patumbak Ibu Muliawati, S.Pd. menunjukkan bahwa kemampuan siswa dalam memahami teks negosiasi masih rendah karena beberapa siswa masih kebingungan dalam memahami setiap materi dalam pembelajaran memahami teks negosiasi sehingga hanya 55\% saja yang tuntas dalam proses pembelajaran memahami teks negosiasi. Menurut penulis berdasarkan pengamatan saat guru sedang mengajar, yang menjadi kendala penyebab kemampuan siswa memahami teks negosiasi rendah adalah kurangnya penerapan model pembelajaran, guru hanya memberi penjelasan mengenai teks negosiasi di depan siswa dan memberikan tugas kepada siswa sehingga siswa menjadi kurang berminat dalam proses pembelajaran.

Menyadari itu, maka kemampuan memahami suatu teks harus dibenahi agar siswa dapat meningkatkan kemampuan memahami teks dalam pembelajaran. Salah satu alternatif pemecahan masalah berdasarkan kendala-kendala yang dihadapi saat proses pembelajaran Bahasa Indonesia penulis menawarkan penggunaan model pembelajaran yang dapat membantu siswa dalam proses pembelajaran sehingga siswa dapat memperoleh nilai yang baik. Model pembelajaran yang ditawarkan untuk mengatasi masalah dalam penelitian ini adalah model pembelajaran make a match.

Pembelajaran model make a match melibatkan siswa sepenuhkan karena guru disini berlaku sebagai pembimbing jalannya diskusi dalam mencocokkan jawaban siswa. Salah satu keunggulan model make a match adalah siswa mencari pasangan sambil belajar mengenai suatu konsep atau topik dalam suasana yang menyenangkan. Keterlibatan siswa jelas terlihat dari bagaimana usaha siswa dalam mencari jawaban yang sesuai dengan pertanyaan. Keterlibatan siswa dalam model make a match dapat dikatakan sebagai pengalaman belajar siswa itu sendiri. Pengalaman belajar merupakan salah satu upaya siswa untuk terus berkembang dan memperluas pengetahuan siswa. 
Hasil penelitian sebelumnya yang dilakukan oleh Riyantika menyatakan bahwa dengan penerapan model pembelajaran kooperatif tipe make a match diperoleh minat dan hasil belajar siswa mengalami peningkatan. Selain itu, hasil penelitian sebelumnya yang dilakukan oleh Ningrum juga menyatakan bahwa model make a match berpengaruh terhadap hasil belajar siswa memahami teks hasil observasi daripada model pembelajaran konvensional.

Berdasarkan uraian di atas, penulis tertarik mengangkat masalah ini sebagai topik penelitian dengan judul "Pengaruh Model Pembelajaran Make a Match terhadap Pemahaman Teks Negosiasi Siswa Kelas X SMK Negeri 1 Patumbak Tahun Pembelajaran 2017/2018.”

\section{METODE PENELITIAN}

Penelitian ini menggunakan pendekatan kuantitatif dengan metode eksperimen. Bentuk desain penelitian yang digunakan adalah desain penelitian one group pre-test post-test design. Arikunto (2013 : 125) berpendapat bahwa one group pre-test post-test design yaitu eksperimen yang dilaksanakan pada satu kelompok saja tanpa pembanding. Desain dengan teknik ini memberikan perlakuan yang sama pada setiap subjek sampel tanpa memperhitungkan dasar kemampuan yang dimiliki. Kesimpulannya siswa yang menjadi sampel dalam penelitian ini akan mendapatkan hak yang sama yaitu tes awal, perlakuan menggunakan model pembelajaran make a macth dalam pembelajaran adalah tes akhir.

Data yang diperoleh hasil tes uji praktik (unjuk kerja), nilai pre-test dan post-test untuk mengetahui prosedural siswa. Nilai pre-test sebelum mendapat perlakuan dan nilai post-test sesudah mendapat perlakuan. Jadi, Metode penelitian eksperimen dengan desain penelitian one group pre-test post-test design dipilih, karena penelitian ini bertujuan untuk mengetahui pengaruh model pembelajaran make a match terhadap pemahaman teks negosiasi siswa kelas X SMK Negeri 1 Patumbak Tahun Pembelajaran 2017/2018 dengan analisis pesyaratan data sampel harus berstatus normal dan homogen kemudian dengan menggunakan uji “t” untuk mengetahui pengaruhnya. 


\section{HASIL PENELITIAN DAN PEMBAHASAN}

\section{A. Hasil Penelitian}

1. Kemampuan Siswa Memahami Teks Negosiasi Sebelum Menggunakan Model Pembelajaran Make a Match

Tabel 1. Hasil Kemampuan memahami Teks Negosiasi Sebelum Menggunakan Model Pembelajaran Make a match

\begin{tabular}{|c|c|c|c|}
\hline Frekuensi & Frekuensi Absolut & Frekuensi Relatif & Kategori \\
\hline $85-100$ & 0 & $0 \%$ & Sangat baik \\
\hline $70-84$ & 7 & $20,6 \%$ & Baik \\
\hline $55-69$ & 6 & $17,6 \%$ & Cukup \\
\hline $40-54$ & 19 & $55,9 \%$ & Kurang \\
\hline $0-39$ & 2 & $5,9 \%$ & Sangat kurang \\
\hline & $\mathbf{3 4}$ & $\mathbf{1 0 0 \%}$ & \\
\hline
\end{tabular}

Tabel di atas menunjukkan bahwa siswa yang berkemampuan dalam kategori sangat baik tidak ada atau 0\%, kategori baik 7 orang atau 20,6\%, kategori cukup 6 orang atau $17,6 \%$, dan kategori sangat kurang 2 orang atau 5,9\%.

2. Kemampuan Siswa Memahami Teks Negosiasi Siswa Kelas X Setelah Menggunakan Model Pembelajaran Make a Match

Tabel 2. Hasil Kemampuan memahami Teks Negosiasi Setelah Menggunakan Model Pembelajaran Make a match

\begin{tabular}{|c|c|c|c|}
\hline Frekuensi & Frekuensi Absolut & Frekuensi Relatif & Kategori \\
\hline $85-100$ & 18 & $52,9 \%$ & Sangat baik \\
\hline $70-84$ & 14 & $41,2 \%$ & Baik \\
\hline $55-69$ & 2 & $5,9 \%$ & Cukup \\
\hline $40-54$ & 0 & $0 \%$ & Kurang \\
\hline $0-39$ & 0 & $0 \%$ & Sangat kurang \\
\hline & $\mathbf{3 4}$ & $\mathbf{1 0 0 \%}$ & \\
\hline
\end{tabular}

Berdasarkan tabel di atas kategori sangat baik 18 orang atau 52,9\%, kategori baik 14 orang atau 41,2\%, kategori cukup 2 orang atau 5,9\%, tidak ada siswa yang berada dalam kategori kurang dan sangat kurang atau 0\%. Melalui perhitungan yang terdapat pada lampiran 10 dapat diperoleh nilai rata-rata sebesar 84,9 dan standar deviasi sebesar 15,6 .

3. Pengaruh model pembelajaran make a match terhadap pemahaman teks negosiasi siswa yaitu menggunakan uji “t”. Analisis yang dilalukan harus dengan persyaratan 
bahwa data yang diteliti berasal dari sampel yang berdistribusi normal dan kelompok yang memiliki varian homogen. Maka berdasarkan uji statistik menggunakan uji " $t$ " diperoleh $\mathrm{t}$ hitung 5,45 yang dikonsultasikan dengan t tabel taraf 5\% dengan $\mathrm{dk}=(\mathrm{N} 1+\mathrm{N} 2)-2=62$ maka diperoleh $\mathrm{t}$ tabel 2,04. Setelah dikonsultasikan, ternyata $t$ hitung lebih besar dari t tabel sehingga dinyatakan $\mathrm{H}_{\mathrm{a}}$ diterima. Hal ini membuktikan bahwa pembelajaran memahami teks negosiasi setelah menggunakan model pembelajaran make a match lebih efektif dibandingkan pembelajaran memahami teks negosiasi sebelum menggunakan model pembelajaran make a match sehingga ditarik kesimpulan bahwa adanya pengaruh model pembelajaran make a macth yang siginifikan terhadap pemahaman teks negosiasi siswa kelas X SMK Negeri 1 Patumbak Tahun Pembelajaran 2017/2018.

\section{B. Pembahasan Penelitian}

1. Kemampuan Memahami Teks Negosiasi Sebelum menggunakan Model Pembelajaran Make a Match

a. Ciri-ciri Teks Negosiasi

Hasil penelitian kemampuan memahami teks negosiasi pada aspek penilaian ciriciri teks negosiasi memperoleh rata-rata 44,24 termasuk dalam kategori kurang. Hal ini terlihat dari jumlah siswa yang menjawab butir soal yang diberikan. Sebanyak 12 orang siswa menjawab benar 1 dari 2 soal mengenai ciri-ciri teks negosiasi atau sebanyak $35,3 \%$ dan sebanyak 22 siswa menjawab benar 2 soal mengenai ciri-ciri teks negosiasi atau sebanyak $64,7 \%$.

b. Struktur Teks Negosiasi

Hasil penelitian kemampuan memahami teks negosiasi pada aspek penilaian struktur teks negosiasi memperoleh nilai rata-rata 65 termasuk dalam kategori cukup. Hal ini terlihat dari siswa yang menjawab 5 soal mengenai struktur teks negosiasi. Sebanyak 9 siswa menjawab satu soal benar atau 26,5\%, 15 siswa menjawab dua soal benar atau 44,2\%, 6 siswa menjawab 3 soal benar atau 17,6\%, 2 siswa menjawab 4 soal benar atau 5,9\%, dan 2 siswa menjawab 5 soal benar atau 5,9\%.

c. Kaidah Kebahasaan 
Hasil penelitian kemampuan memahami teks negosiasi pada aspek penilaian kaidah kebahasaan dengan jumlah 10 soal memperoleh nilai rata-rata 65,2 termasuk kategori cukup. Hal ini terlihat dari banyaknya siswa yang menjawab 1 soal benar sebanyak 1 siswa atau 2,9\%, 2 soal benar sebanyak 1 siswa atau 2,9\%, 3 soal benar sebanyak 10 siswa atau 29,5\%, 4 soal benar sebanyak 4 siswa atau 11,8\%, 5 soal benar sebanyak 4 siswa, 6 soal benar sebanyak 7 siswa atau 20,6\%, 7 soal benar sebanyak 5 siswa atau 14,7\%, 8 soal benar sebanyak 1 siswa atau 2,9\%, dan 9 soal benar sebanyak 1 siswa atau $2,9 \%$.

\section{d. Pengertian, Fungsi Dan Tujuan Teks Negosiasi}

Hasil penelitian kemampuan memahami teks negosiasi pada aspek penilaian pengertian, fungsi dan tujuan teks negosiasi memperoleh rata-rata 68 dan termasuk dalam kategori cukup. Hal ini terlihat dari banyaknya siswa yang hanya mampu menjawab 8 soal mengenai aspek pengertian, fungsi dan tujuan teks negosiasi. Sebanyak 1 siswa menjawab 2 soal benar atau 2,9\%, 4 siswa menjawab 3 soal benar atau 11,8\%, 11 siswa menjawab 4 soal benar atau 32,4\%, 13 siswa menjawab 5 soal benar atau 38,3\%, 3 siswa menjawab 6 soal benar atau 8,8\%, 1 siswa menjawab 7 soal benar atau 2,9\%, dan 1 siswa menjawab 8 soal benar atau 2,9\%.

\section{Kemampuan Memahami Teks Negosiasi Setelah Menggunakan Model Pembelajaran Make a Match}

a. Ciri-ciri Teks Negosiasi

Hasil penelitian kemampuan memahami teks negosiasi pada aspek penilaian ciriciri teks negosiasi memperoleh rata-rata 66,02 termasuk dalam kategori cukup. Nilai rata-rata pada aspek Ciri-ciri teks negosiasi mengalami peningkatan sebanyak 21,78\%. Hal ini terlihat dari jumlah siswa yang menjawab butir soal yang diberikan. Sebanyak 1 orang siswa menjawab benar satu dari dua soal mengenai ciri-ciri teks negosiasi atau sebanyak 2,9\% dan sebanyak 33 siswa menjawab benar dua soal mengenai ciri-ciri teks negosiasi atau sebanyak $97,1 \%$.

b. Struktur Teks Negosiasi

Hasil penelitian kemampuan memahami teks negosiasi pada aspek penilaian struktur teks negosiasi memperoleh nilai rata-rata 80,52 termasuk dalam kategori baik. 
Nilai rata-rata pada aspek struktur teks negosiasi mengalami peningkatan sebanyak $15,52 \%$. Hal ini terlihat dari siswa yang menjawab 5 soal mengenai struktur teks negosiasi. Sebanyak 1 siswa menjawab satu soal benar atau 2,9\%, 1 siswa menjawab 3 soal benar atau 2,9\%, 19 siswa menjawab 4 soal benar atau 55,9\%, dan 13 siswa menjawab 5 soal benar atau $38,3 \%$.

\section{c. Kaidah Kebahasaan}

Hasil penelitian kemampuan memahami teks negosiasi pada aspek penilaian kaidah kebahasaan dengan jumlah 10 soal memperoleh nilai rata-rata 87,4 termasuk kategori sangat baik. Nilai rata-rata yang diperoleh pada aspek kaidah kebahasaan meningkat sebesar 22,2\%. Hal ini terlihat dari banyaknya siswa yang menjawab 5 soal benar sebanyak 2 siswa atau 5,9\%, 6 soal benar sebanyak 3 siswa atau 8,8\%, 7 soal benar sebanyak 4 siswa atau 11,8\%, 8 soal benar sebanyak 8 siswa atau 23,5\%, 9 soal benar sebanyak 7 siswa atau 20,6\%, dan 10 soal benar sebanyak 10 siswa atau 29,4\%.

d. Pengertian, Fungsi Dan Tujuan Teks Negosiasi

Hasil penelitian kemampuan memahami teks negosiasi pada aspek penilaian pengertian, fungsi dan tujuan teks negosiasi memperoleh rata-rata 72 dan termasuk dalam kategori baik. Nilai rata-rata pada aspek pengertian, fungsi dan tujuan teks negosiasi mengalami peningkatan sebanyak $4 \%$. Hal ini terlihat dari banyaknya siswa yang hanya mampu menjawab 8 soal mengenai aspek pengertian, fungsi dan tujuan teks negosiasi. Sebanyak 4 siswa menjawab 5 soal benar atau 11,8\%, 7 siswa menjawab 6 soal benar atau 20,6\%, dan 23 siswa menjawab 7 soal benar atau 67,6.

\section{Pengaruh Model Pembelajaran Make a Match terhadap Kemampuan Memahami Teks Negosiasi Siswa Kelas X SMK Negeri 1 Patumbak Tahun Pembelajaran 2017/2018}

Hasil rata-rata kemampuan memahami teks negosiasi sebelum menggunakan model pembelajaran make a match 54 dari jumlah siswa sebanyak 34 dengan nilai tertinggi 84 dan nilai terendah 36 sedangkan data dikontribusikan dalam kategori baik sebanyak 7 orang atau 20,6\%, kategori cukup sebanyak 6 orang atau 17,6\%, kategori kurang sebanyak 19 orang atau 55,9\%. Uji normalitas kelas sebelum menggunakan model pembelajaran make a match dengan uji lilifoers $\mathrm{L}_{\text {tabel }}=0,1485$. Dengan 
demikian $\mathrm{L}_{\text {hitung }}<\mathrm{L}$ tabel yaitu $(0,346<0,1485)$ dengan demikian data pada kelompok pre-test berdistribusi normal.

Hasil rata-rata kemampuan memahami teks negosiasi setelah menggunakan model pembelajaran make a match 84,5 dari jumlah siswa sebanyak 34 orang dengan nilai tertinggi 96 dan nilai terendah 60 sedangkan data dikontribusikan dalam kategori sangat baik sebanyak 18 orang atau 52,9\%, kategori baik sebanyak 14 orang atau 41,2\% dan kategori cukup sebanyak 2 orang atau 5,9\%. Identifikasi kelompok post-test ini termasuk normal dan termasuk dalam kategori yang baik. Uji normalitas kelompok post-test dengan uji Liliefors $\mathrm{L}_{\text {tabel }}=0,1485$. Dengan demikian $\mathrm{L}_{\text {hitung }}<\mathrm{L}$ tabel yaitu $(0,0006<0,1485)$ ini membuktikan bahwa data dari kelompok post test berdistribusi normal. Data kelompok pre-test dan kelompok post-test memiliki varians yang homogen. Hal ini ditunjukkan sesuai dengan perhitungan $F_{\text {hitung }}<F_{\text {tabel }}$ yaitu 1,57 < 1,80. Sehingga data kelompok pre-test dan kelompok post test dapat dilanjutkan untuk diuji analisis hipotesis.

Hasil penelitian menunjukkan bahwa rata-rata kemampuan memahami teks negosiasi setelah menggunakan model pembelajaran make a match lebih tinggi sebelum menggunakan model pembelajaran make a match. Hal ini menunjukkan bahwa penggunaan model pembelajaran make a match efektif digunakan untuk membantu siswa terhadap pembelajaran memahami teks negosiasi siswa kelas X SMK Negeri 1 Patumbak Tahun Pembelajaran 2017/2018. Hal tersebut dibuktikan dari hasil uji hipotesis, diperoleh $t_{\text {hitung }}$ lebih besar dari $t_{\text {tabel }}$ yaitu 45,45> 2,04 maka $h_{a}$ diterima yang membuktikan adanya pengaruh yang signifikan terhadap kemampuan memahami teks negosiasi setelah menggunakan model pembelajaran make a match.

\section{PENUTUP}

Berdasarkan hasil penelitian dan pembahasan, ditarik kesimpulan bahwa kemampuan siswa memahami teks negosiasi sebelum menggunakan model pembelajaran make a match menunjukkan hasil dengan nilai tertinggi 84 dan nilai terendah 36 yang memiliki nilai rata-rata 54 dan berada pada kategori kurang. Kemampuan siswa memahami teks negosiasi setelah menggunakan model pembelajaran make a match menunjukkan hasil dengan nilai tertinggi 96 dan nilai terendah 60 yang 
memiliki nilai rata-rata 84,9 dan berada pada kategori baik. Terdapat pengaruh yang signifikan terhadap penggunaan model pembelajaran make a match terhadap kemampuan memahami teks negosiasi siswa kelas X SMK Negeri 1 Patumbak Tahun Pembelajaran 2017/2018. Pembuktiannya diperoleh dari hasil uji hipotesis bahwasannya $t_{\text {hitung }}$ lebih besar dari $t_{\text {tabel }}$ yaitu 5,54>2,04 maka hipotesis $H_{a}$ diterima yang membuktikan adanya pengaruh yang signifikan terhadap kemampuan memahami teks negosiasi setelah menggunakan model pembelajaran make a match.

\section{DAFTAR PUSTAKA}

Arikunto, Surhasimi. 2013 Prosedur Penelitian suatu Pendekatan Praktik. Jakarta : PT. Rineka Cipta.

Daryanto. 2011. Media Pembelajaran . Bandung:Penerbit Satu Nusa.

Kemendikbud. 2016. Buku Bahasa Indonesia. Jakarta.

Nurgiyantoro, Burhan. 2014. Prosedur Penelitian Suatu Pendekatan Praktis. Jakarta : Rineka Cipta.

Suprijono. 2009. Cooperative Learning. Yogyakarta: Pustaka Pelajar.

Banjarnahor, Lastria. 2010. Efektifitas Metode Resiprocal Teaching dalam Meningkatkan Kemampuan Memahami Teks Negosiasi Siswa Kelas X SMA Swasta Parulian 2 Medan Tahun Pembelajaran 2009/2010. Skripsi. Medan. Unimed. 